\title{
ゴム材料の微生物による変質・劣化 について
}

\author{
——防水剂・パッキングなどの微生物災害
}

\section{井 上 真由美*}

\section{1. 微生物の作用の範囲}

微生物は，地球上に非常に古くから存在したといわれ ている. アフリカの岩石には大昔の微生物の化石と思わ れるものが含まれていて，その年代は調查の結果，今か ら約30億年も前のものといらことが明らかにされている

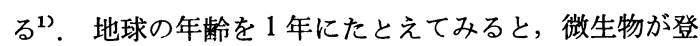
場したのは 3 月 20 日ごろであり，人間があらわれたのは 12月 31 日の午後 7 時すぎといら計算になることからもわ かるよらに，微生物のほらがはるかに大先輩といわなけ ればならない，人間の生活は，微生物とともにあるとい らことを十分に理解し，われわ机の日常生活から微生物 と縁を切ることは絶対に不可能であるといえる。

微生物を取扱ら専門分野は医学と農学といらのが従来 の大きな特徴となっている. しかしながら筆者の長年に わたる広い範囲の微生物災害の研究から工業材料・産業 資材の重要な材料がかびやバクテリアの作用で変質・劣 化・崩壊・腐食の害を受けることが明らかになった。こ の現象を微生物災害(Microbial Deterioration) といい, 国際的にもシンポジウムが開かれている2゙．微生物の作 用を受けるものは，今までの研究成果から主として次に 示すものである゙

1) アルミニウム（航空機・建材・はくなど）

2 ）鉄及び銅 (水道管・冷却器・プリント基板)

3) 天然ゴム (パッキング・シートなど)

4) ポリウレタン樹脂 (パッキング・防水樹脂など)

5) ポリ塩化ビニル樹脂（建材・防水樹脂など）

6) エポキシ樹脂（建材・機械・防水樹脂・エレク トロニクス)

7 ) シリコン樹脂 (エレクトロニクス)

* 井上微生物災害研究所

(テ177 東京都練馬区関町1-163)
8 ） アクリル樹脂 （ライニンク・建材）

9 ) 複合材料（各種の用途におけるもの）

10) 塗料及び接着剤

11) 石油製品（圧延油・切削油）

12）レンズ・プリズム（カメラ・顕微鏡・測定 機 器 など)

13）繊維材料（衣料・工業用・内装用・装飾用など）

14）木材（建築用・家具用・美術工芸品用）

微生物は, 自然界では土袞 $1 \mathrm{~g}$ 中に約 1 億が生存して いる. 微生物は動物・植物の遺体や排せつ物中の有機物 を分解して無機物に変える働きをしている．そのために 不用になったものは，すべて微生物の作用で分解・崩壊 し最終的には消滅する運命にある。これは大自然の正常 な循環であって，そのバランスは，われわれが生きてい くために最も重要な問題といわなければならない，とこ ろが人間の勝手な都合と利益だけにとらわれて大きな都 会を作り，地表をすべてコンクリートやアスファルトで 固めてしまらと地表から酸素や水が土袞中一供給されな いために微生物の力が十分に作用しないよらな環境にな ってしまう．そのような状態では植物むよく生育するこ とができない，また，大量のプラスチックを一度にうめ たり捨てたりすると微生物の作用が完全にいとなまれな くなり，自然のリサイクリングに大きな障害となり分解 が止ってしま5.

\section{2.ゴムの微生物による障害}

NR は天然の材料であるため微生物によって攻撃を受 けやすい物質と考えるべきであろら，建築・土木の関係 の防水材料, 石油基地のパッキング, 化学プラントなど でゴム材料が広く用いられている。一部では天然ゴムの 代わりに SBR やポリウレタン・ポリ塩化ビニルが用い られている. 筆者の研究所で取り扱った例について述べ 
る.

1971年に首都高速道路公団の依頼によって, 東京湾の 海底に設施する海底道路に使用するコンクリートの内部 に埋めこむ防水樹脂の微生物抵抗性についての調查研究 を行った. 次の 3 項目の条件によって微生物抵抗性を試 験した.

1) 東京湾海底のへドロ中に 6 か月間以上材料を浸漬 し，1か月ごとに劣化の状態を観察した.（図 1 )

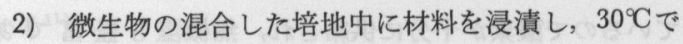
菌を活動させ材料の変化を観察した. 菌としては次 の 5 種のものを用いた.

$\begin{array}{ll}\text { Pseudomonas aeruginosa } & \text { （シュードモナス菌） } \\ \text { Pseudomonas fluorescens } & \text { (シュードモナス菌) } \\ \text { Proteus vulgaris } & \text { (変形菌) } \\ \text { Escherichia coli } & \text { (大腸菌） } \\ \text { Bacillus subtilis } & \text { (枯草菌） }\end{array}$

ここに用いた菌は，すべて土壌や水のなかに多く生存 し強力な酸素力をもち, 材料を分解する力が強い種類で ある.

3）かび抵抗性試験を行って材料の劣化を試験した.

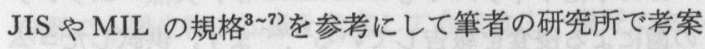
した方法で実施した.ばれいし抽出液とぶどう糖を含有 する平板寒天培地を作り，その表面に図 2 に示すよらに 材料をおき, 次の 6 種のかびの胞子液を噴霧し， $30^{\circ} \mathrm{C}$, 湿度95士5\% R.H. に 6 か月保存して，かびの菌系を 増殖させて材料への影響を調査した。

$\begin{array}{ll}\text { Aspergillus niger } & \text { (黒かび) } \\ \text { Aspergillus flavus } & \text { (こうじかび) } \\ \text { Cladosporium herbarum } & \text { (クラドスポリウム) } \\ \text { Aureobasidium pullulans } & \text { (オーレオバシディウム) } \\ \text { Penicillium citrinum } & \text { (青かび) } \\ \text { Fusarium moniliforme } & \text { (フザリウム) }\end{array}$
かびも強力な分解酵素を生産する.

実際に試験を行った材料は，次のとおりである.

1) ポリウタレン樹脂

2) エポキシ樹脂

3) ポリ塩化ビニル樹脂

4) イソプレン・イソブチレンゴム(IIR)

5) アスファルト

上述の 3 種の試験の結果, 外見的にも材料の強度低下 の点でもポリウタレン樹脂とアスファルトが最も短期間 ( 1 ～ 2 か月以内) で激しく変形・劣化することか゚わかっ た. (図 3 )それについで微生物劣化が発生し, 変形する 材料は, ポリ塩化ビニル樹脂である. エポキシ樹脂は最

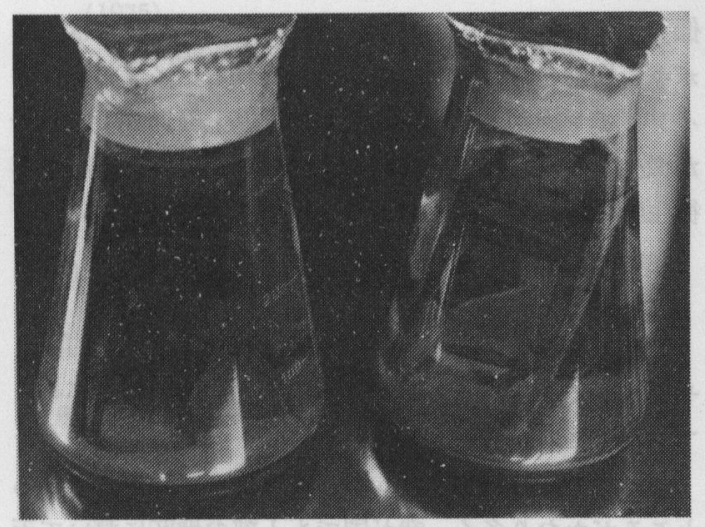

図 1 ヘドロ液中に試料を浸せき中

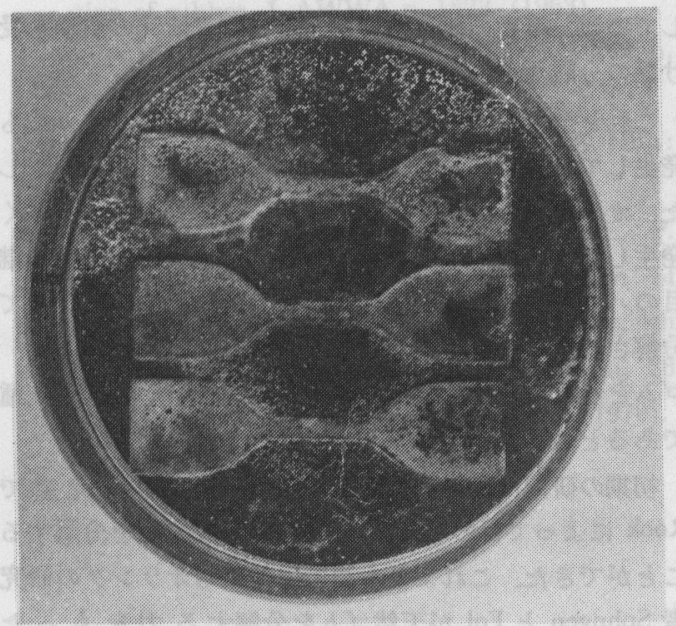

図 2 試料を平枚培地上におき試験菌を接種する.
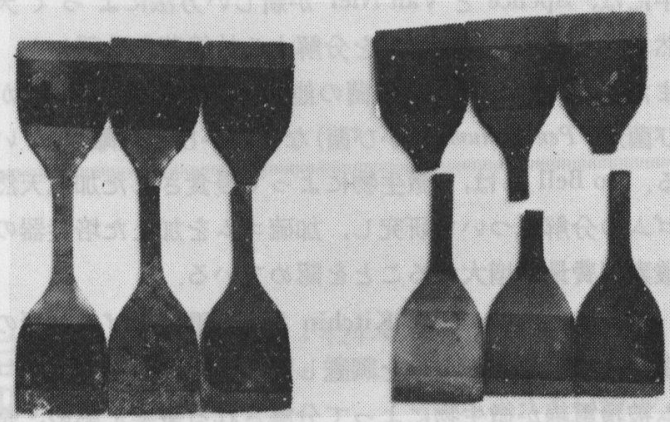

図 3 ポリウレタン防水材のかびによる変質劣化

初の 3 か月間は, 表面に微生物が増殖しない. 強度の低 下む起こらないので微生物に対して抵抗性があるように 思われたが， 4 か月を過ぎるころから急に菌が増殖する よらになり，材料の変色が起こり，機械的強度も急速に 
低下することが明らかにされた. このような性質は，エ ポキシ樹脂のもつ特徴のように思われる. イソプレン・ イソブチレンゴム(IIR) は， 6 か月以上経過しても材料 が微生物に侵されず, 強度も低下しなかったため, 最も 微生物に対して抵抗性をもつといら判定となった.

\section{3. パイプの継目材料の微生物劣化}

地下に埋設された水道の配水管は鋳鉄管以外に石綿と セメントで作られた石綿管が使用され，多くの量が今日 でも地下に埋設使用されている.

パイプの断目に天然ゴムのパッキングが使われている ところがかなり多く，我が国でも 1 部の地区において天 然ゴムが土壤菌によって侵食され，漏水事故が多く発生 している. 筆者の研究所では，その調查研究の依頼を受 け菌の分離などの研究を行っている.

これと全く同じような事故がオランダとアメリカでも 発生している. 1930年にオランダでは, 水道が普及し た. オランダの西部及び北部では，水道管の漏水が多く 発生したのは1949年のことである. 水道管の石綿管の継 目のパッキングには天然ゴムが使われ，土壌菌によって 分解されたのが原因であることが調査の結果わかった. ゴムを侵食した土壌菌は放線菌(Streptomycse sp.)の 1 種 であると報告されている.

初期の研究は, デルフト工科大学の微生物 研 究 室 で Rookによって行われた. 石綿管から放線菌を分離する ことができた. これよりむ更に以前にもオランダの研究 者 Sohngen と Fol が天然ゴムを分解する力をもった Actinomyces（放線菌と同じ)を分解している．更に 1936 年には, Spence と V a N Niel が新しい方法によって天 然ラテックスの炭化水素を分解する放線菌を分離した. また Kalinenko は，放線菌の他にAspergillus（こうじか び菌)や Penicillium(青かび菌)などのかびも分離してい る. Zo Bell らは，微生物によって侵食された加硫天然 ゴムの分解について研究し, 加硫ゴムを加えた培養器の 酸素消費量が増大寸ることを認めている.

1950年には Brake と Kitchin らは，電線のゴム被覆の 微生物による劣化現象を調查した. 土中に埋設されたゴ ム被覆電線が微生物によって分解される事実を認め, 特 に天然ゴムの部分に微細な孔があくことを認め，これは 微生物の作用によってできるものと考えた.

1963年 Leeflang は,オランダ各地の漏水現場から天然 ゴムリングを集めて微生物を検出している. ゴムリング には，一般に菌のスライムが一面に付着している．ぶど ら糖とペプトンを含む寒天培地の平板上にゴムリングの
小片をぬりつけて培養し, 菌のコロニーが数日後に発育 し，放線菌が検出された ${ }^{8)}$. Sohngen と Fol の分離した 菌と同一である。

Leeflaug は, 更に純粋培養で天然ゴム分解能力のある 微生物についてくわしく調べ，放線菌が天然ゴムの炭素 を強力に分解することをたしかめることができた.

天然ラテックスの加硫天然ゴムを分解する菌の役割 は，次のように考えられる．水道管内は絶えず水が流れ ているので酸素が十分に供給され，無機塩も豊富であ る.ゴムリングの内側に菌が多く生育してゴムを破壊す る. 水に接した部分だけではなく，土壌に接した部分で もゴムが破壊される場合がある。これは地下水が酸素を 含んでいるためと考えられる.

加硫ゴムを用いる方法によって数週間あるいは数か月 の浸せき期間に菌がゴムリングから分離される．この菌 は，自然界に非常に多く分布している。この菌は好気性 であるため, 酸素の存在を必要とする. しかし，硝酸塩 を還元する力をもっているので, 酸素がなくてもゴムリ ングを分解することができる.

1965年にイギリスでも Dickenson が，天然ゴムリング の菌による侵食を報告している9 。 。ず，供試したゴム リングの化学分析をしてみるとゴムリングは, 殆ど抗酸 化剂を含んでいなかった. 更にフェニルベータナフチル アミンが検出された．その量は，ポリマーあたり $0.1 \sim$ 0.3である. ゴムリング中の抗酸化剂が少ないのは，化 学酸化又は水による溶脱又は菌による分解によるもので ある.イギリスのゴムリングの分析結果では銅の含有量 が普通のものの200倍も存在していることがわかった.こ れは銅が触媒する酸化によるものと考えられる.ゴムリ ングの分解は，銅の存在で更に促進される。

イギリスのゴムリングに高含有量の銅が検出され, 又 多くの放線菌が分離されている. そのなかで Streptomyces とNocardia が主でこの 2 種の菌は形態がよく類似して いる. また放線菌以外に天然ゴムを分解する菌には, 次 の種類のかびが報告されている10).
1) Aspergillus (こうじかび)
2) Penicillium （青かび）
3) Alternaria （アルテリナリア菌）
4) Paecilomyces (パエシロミセス菌)
5) Fusarium (フザリウム菌)

筆者の研究所では, 現在のところ Penicillium sp. Fusarium sp. Cladosporium sp. Scolecobasidium sp. Pestalotia sp. な どが分離され，更にくわしく研究中である. 
1978年 8 月28日から Berlin の Dahlemにある Bundesanstalt für Materialprufüng (BAM)（国立材料試験所） で開かれた 4th International Biodeterioration Symposium に出席した. このシンポジウムでもポーランドの Kwiaktowskaらが，天然ゴムの微生物劣化の 研究を発 表した. 土壌中で使用中の天然ゴムから圧倒的に多く Fusarium sp. (フザリウム菌)が分離され，これが天然ゴ ムの微生物による変質劣化の主役であることを確認して いる11).

\section{4. 今後の重要課題}

我が国においてもようやく最近になって異なる専門分 野にわたる学術を有機的に結びつけていわゆる境界領域 の学術の価値が理解されるようになった．従来からの考 えでは，全く無関係とされた異なる専門的内容が学術や 忘用方面の多様化によって深い関係をもつことが発見さ れ，たがいに広い視野から有機的に結びつけることによ って今まで解明されなかったことが解決への 1 つの方向 がひらけるといら進歩的な方法といえる. microbial det erioration の研究もその 1 つの例で, 建築・土木などの 分野でも微生物の知識を考慮して今後は広い視野に立っ て考えて行くことを念願している.

〔付記〕本稿は昭和53年10月20日開催の第 9 回ゴム科学 技術研究委員会において講演したものである。

\section{引用 文 献}

1) 朝日新聞科学部編：小さな 小さな 敵と味方,
(1975).

2) The Biodeterioration Society: President, Dr. D. Allsopp, Biodeterioration Information Center, University of Aston, 80, Coleshill Street, Birmingham B4 7PF, England.

3）井上真由美 : アルミニウムの微生物腐食, 軽 金属出版社，(1972).

4) 井上真由美：応用微生物の方向，植 書 店, (1970).

5) 井上真由美 : 続 - 応用微生物の方向, 桧書店, (1972)

6) 井上真由美 : 微生物による変質腐食と対策, 化学工業社，(1972).

7）井上真由美：微生物災害 と防止技術，工学図 書, (1977).

8) K. W. H. Leeflang: Microbiological degradation of rubber, J. AWWA p. 1523, (1963).

9) P. B. Dickenson: J. Rubber Res Inst. Malaya, p. 165, (1969).

10) A. M. Cundell, A. P. Mulcock and D. A. Hills: Rubber J. p. 22, (1973).

11) D. Kwiatkowska, B. J. Zyska and L. P. Zankowicz: Microbiological deterioration of natural rubber sheet by soil microorganisms, 4th International Biodeterioration Symposium, 28 August to 2 September, Berlin-Dahlem, (1978).

申込先：日本ゴム協会 図書係あて（干107 東京都港区元赤坂 1-5-26 東部ビル内） 